\section{Contributions:}

A Study design/planning

B Data collection/entry

C Data analysis/statistics

D Data interpretation

E Preparation of manuscript

F Literature analysis/search

$\mathrm{G}$ Funds collection

\title{
A REVIEW OF HEARING AID TELECONSULTATION IN BRAZIL
}

\section{Deborah Viviane Ferrari ${ }^{1 A B C D E F G}$, Esteban Alejandro Lopez ${ }^{2 A B C D E F G}$}

${ }^{1}$ Department of Speech-Language Pathology and Audiology, Dental School of Bauru, University of Sao Paulo, Bauru, Brazil

${ }^{2}$ Inter-Unit Program on Bioengineering, Sao Carlos School of Engineering, University of Sao Paulo, Sao Carlos, Sao Paulo, Brazil

Corresponding author: Deborah Ferrari, Dental School of Bauru, University of Sao Paulo, Al. Octavio Pinheiro Brisola 9-75, Vila Universitária, Bauru, Sao Paulo, Brazil 17012-901, e-mail: deborahferrari@usp.br

\begin{abstract}
Since 1993, Brazil's public Unified Health System (SUS) has been enhancing the provision of hearing healthcare services, ranging from prevention to intervention. The provision of quality services is challenged by the country's large size, socio-economic contrasts, poorly distributed infrastructure, and the concentration of qualified audiology professionals in metropolitan areas. It is estimated that 14 million Brazilians have a disabling hearing impairment - a number already beyond service capacity. Increased life expectancy enlarges the prevalence of hearing impairment, further saturating the system. Ongoing societal changes call for alternative approaches to healthcare - one of them being telehealth. This paper describes the milestones in the development of hearing healthcare public policies in Brazil and discusses the main concepts behind the provision of services via telehealth and the implementation of the Brazilian Telehealth Networks Program. Furthermore, the results and implications of research on remote hearing aid fitting, conducted at Bauru Dental School, are presented. This review indicates that issues such as shortage of audiologists, lack of the use of real ear measures, and patient absenteeism could be mitigated by incorporating remote hearing aid fitting routinely in public hearing healthcare clinics. But in order to implement this approach, more constructive interactions among different stakeholders is required. Overall, telehealth has the potential to help healthcare providers meet the demands of a technologically increasing society.
\end{abstract}

Key words: eHealth $\bullet$ telehealth $\bullet$ telemedicine $\bullet$ hearing aids $\bullet$ audiology

\section{TELECONSULTAS RELATIVAS A LOS AUDÍFONOS EN BRASIL - REVISIÓN}

\section{Resumen}

A partir del año 1993 el sistema sanitario de Brasil (SUS) va aumentando la prestación de los servicios sanitarios relativos al aparato auditivo, desde la prevención hasta la intervención. Garantizar una alta calidad de los servicios es un reto debido a la gran superficie del país, las diferencias socioeconómicas, una infraestructura mal distribuida, así como por el hecho de concentrarse los audiólogos en los terrenos urbanos. Se estima que 14 millones de brasileños padecen una pérdida de la audición discapacitante - este número ya hoy día supera las posibilidades del sistema. El aumento de la esperanza de vida origina el crecimiento en la frecuencia de los trastornos auditivos, lo cual sobrecarga incluso más el sistema. Los cambios sociales que están en curso requieren métodos sanitarios alternativos, uno de los cuales es precisamente la telesalud. El presente trabajo describe los hitos del desarrollo de la política pública de Brasil, relativos a la asistencia sanitaria con respecto al aparato auditivo. Además, se discuten las suposiciones principales relativas a la prestación de los servicios por medio del método de telesalud y la puesta en marcha del programa de La Red Nacional de Telesalud de Brasil (Brazilian Telehealth Networks Program). El trabajo presenta también los resultados y las recomendaciones con relación a las investigaciones que tienen como fin adaptar los aparatos auditivos a distancia, llevadas a cabo en la Escuela Superior de Estomatología de Bauru. La revisión descrita demuestra que los problemas tales como un número insuficiente de audiólogos, el hecho de no utilizar las mediciones realizadas al oído real en vivo así como el de no comparecer los pacientes a las consultas pueden quedar aliviados a través de la implementación de forma fija en los centros sanitarios que se ocupan del aparato auditivo de la adaptación de los audífonos a distancia. No obstante, para poder implementar este método se requieren unas interacciones más constructivas entre los diferentes socios. En general, el método de telesalud conlleva un potencial que les puede ayudar a los prestadores de servicios sanitarios a hacer frente a las necesidades de una sociedad que se desarrolla desde el punto de vista tecnológico.

Palabras claves: eSalud $\bullet$ telesalud $\bullet$ telemedicina $\bullet$ aparatos auditivos • audiología 


\title{
ТЕЛЕКОНСУЛЬТАЦИИ ДЛЯ НУЖД СЛУХОВЫХ АППАРАТОВ В БРАЗИЛИИ - ОБЗОР
}

\author{
Изложение
}

С 1993 года система социального здравоохранения в Бразилии (SUS) увеличивает предоставление здравоохранительных услуг в области органов слуха, начиная с профилактики, заканчивая вмешательством. Обеспечение высокого качества услуг является проблемой в связи со значительными масштабом страны, социально-экономическими различиями, слабо развитой инфраструктурой, а также сосредоточением квалифицированных аудиологических кадров на городских территориях. Исследователи оценивают, что 14 миллионов бразилийцев страдает от вызывающей инвалидность тугоухости - это число уже сейчас превышает возможности системы. Увеличение средней продолжительности жизни вызывает рост количества случаев появления дефектов слуха, что ещё сильнее обременяет систему. Происходящие общественные изменения требут альтернативных методов здравоохранения - одним из них как раз является телездравоохранение. В настоящей работе представлены вехи в развитии социальной политики в Бразилии, относящиеся к здравоохранению в области органов слуха. Кроме того, были обсуждены главные принципы предоставления услуг методом телездравоохранения и внедрение программы Общегосударственной сети телездравоохранения в Бразилии (Brazilian Telehealth Networks Program). Дополнительно в работе представлены результаты и рекомендации, касающиеся исследований над подбором слуховых аппаратов на расстояниии, проведённых в Высшей стоматологической школе в Бауру. Представленный обзор показывает, что такие проблемы, как недостаточное количество аудиологов, отсутствие измерений на живом ухе и непоявление пациентов, можно уменьшить, внедряя на постоянной основе в учреждениях здравоохранения подбор слуховых аппаратов на расстоянии. Однако чтобы можно было внедрить данный метод, требуются более конструктивные контакты между разными партнёрами. В общей перспективе метод телездравоохранения проявляет потенциал, чтобы помочь поставщикам здравоохранительных услуг соответствовать потребностям технологически развивающегося общества.

Ключевые слова: е-Здравоохранение • телездравоохранение • телемедицина • слуховые аппараты • аудиология

\section{TELEKONSULTACJE DLA POTRZEB APARATÓW SŁUCHOWYCH W BRAZYLII - PRZEGLĄD}

\section{Streszczenie}

Od 1993 roku system publicznej opieki zdrowotnej w Brazylii (SUS) zwiększa świadczenie usług opieki zdrowotnej nad narządem słuchu, począwszy od prewencji po interwencję. Zapewnianie wysokiej jakości usług stanowi wyzwanie z powodu znacznych rozmiarów kraju, różnic socjoekonomicznych, słabo rozlokowanej infrastruktury, oraz skupiania się wykwalifikowanej kadry audiologicznej na terenach miejskich. Szacuje się, iż 14 milionów Brazylijczyków cierpi na powodujący inwalidztwo niedosłuch - liczba ta już teraz przewyższa możliwości systemu. Zwiększenie średniej długości życia pociąga za sobą wzrost występowania wad słuchu, co jeszcze bardziej obciąża system. Toczące się zmiany społeczne wymagają alternatywnych metod opieki zdrowotnej - jedną z nich jest właśnie telezdrowie. W niniejszej pracy opisano kamienie milowe w rozwoju polityki publicznej w Brazylii, odnoszące się do opieki zdrowotnej nad narządem słuchu. Ponadto, omówiono główne założenia dotyczące świadczenia usług metodą telezdrowia oraz wprowadzanie w życie programu Krajowej Sieci Telezdrowia w Brazylii (Brazilian Telehealth Networks Program). Dodatkowo, w pracy zaprezentowano wyniki i wskazania dotyczace badań nad dopasowaniem aparatów słuchowych na odległość, przeprowadzonych w Wyższej Szkole Stomatologicznej w Bauru. Prezentowany przegląd pokazuje, iż problemy takie jak niedostateczna liczba audiologów, brak korzystania z pomiarów na żywym uchu oraz niestawianie się pacjentów, można załagodzić, wdrażając na stałe do placówek opieki zdrowotnej nad narządem słuchu dopasowanie aparatów słuchowych na odległość. Jednak aby móc wdrożyć tę metode, wymagane są bardziej konstruktywne interakcje między różnymi partnerami. W ogólnym zarysie, metoda telezdrowia wykazuje potencjał, by pomóc dostawcom świadczeń zdrowotnych sprostać potrzebom rozwijającego się technologicznie społeczeństwa.

Słowa kluczowe: eZdrowie $\bullet$ telezdrowie $\bullet$ telemedycyna $\bullet$ aparaty słuchowe $\bullet$ audiologia

\section{The unified health system: A brief description}

The Federative Republic of Brazil is the largest country in Latin America in both area and population (Table 1). With a gross domestic product of US $\$ 1.7$ trillion, Brazil is currently the ninth largest world economy. Between 2003-11, poverty in the country decreased from $26.7 \%$ to $12.6 \%$ of the population. Extreme poverty (living on US $\$ 1.25 /$ day) decreased from $11.2 \%$ to $5.4 \%$ of the population in the same period [1]. The Municipal Human Development Index, which takes into account indicators such as education, longevity, and income, grew $47.5 \%$ between 1991 and 2010 [2].

Despite these achievements, great income inequality is still evident in Brazilian society. About $47.5 \%$ of the population live on a monthly income of US\$250 (the minimum wage) [3] or less, as of October 2016. There are also striking regional differences within the country (e.g. the South and Southeast against the North and Northeast) in terms of population density, infrastructure, and economic and technological development [1-3]. The result is that in a large proportion of the population is at increased health risk, since health problems correlate with socioeconomic factors.

Brazil has a mixed health system formed of a large public sector, the Unified Health System (in Portuguese, Sistema Único de Saúde - SUS), together with a private sector of supplemental health companies and out-of-pocket payments [6]. Although distinct, the sectors are intertwined and people can use any of these services depending on the 
Table 1. Brazil's sociodemographic and economic indicators

\begin{tabular}{|c|c|}
\hline Territory & $8,515,767 \mathrm{~km}^{2}$ \\
\hline Number of states & 26 \\
\hline Number of municipalities & 5570 \\
\hline Population & $204,450,649$ \\
\hline $\begin{array}{r}\text { Distribution by region [2] } \\
\text { Urbanization rate [2] }\end{array}$ & $\begin{array}{l}\text { North }(8.5 \%) \text {; Northeast }(28 \%) \text {; South }(14 \%) \text {, Southeast }(42 \%) \text {; } \\
\text { Midwest }(7.5 \%)\end{array}$ \\
\hline & $84.8 \%$ \\
\hline Distribution by age group (years) [2] & $\begin{array}{l}\text { 0-9 (14.1\%); 10-19 (16.9\%); 20-29 (15.7\%); 30-60 (40.4\%); } 60 \\
\text { or more (13.1\%) }\end{array}$ \\
\hline Life expectancy [4] & 75.2 yrs (men 71.8; women 78.8) \\
\hline $\begin{array}{l}\text { Average number of schooling years [3] } \\
\text { (population } \geq 25 \text { yrs old) }\end{array}$ & 7.7 \\
\hline Distribution by age group & 25-64 yrs old: $8.3 ;>65$ yrs old: 4.2 \\
\hline Illiteracy rate (population $\geq 15$ yrs old) [2] & $8.5 \%$ \\
\hline Distribution by region & $\begin{array}{l}\text { North }(9.5 \%) \text {; Northeast }(16.9 \%) \text {; South }(4.6 \%) \text {; Southeast } \\
(4.8 \%) ; \text { Midwest }(6.5 \%)\end{array}$ \\
\hline Gross Domestic Product (GDP) [1] & USD 1.7 trillion \\
\hline Gross National Income (GNI) per capita [1] & USD 9,850 \\
\hline $\begin{array}{l}\text { Income - minimum wage multiples [2] } \\
(1=\text { USD } 250 \text { approx. })\end{array}$ & $\begin{array}{l}>5: 4.8 \% \\
\text { No income: } 2.4 \% \\
\text { Not declared: } 4.8 \%\end{array}$ \\
\hline Unemployment rate (population $\geq 16$ yrs old) [2] & $6.4 \%$ \\
\hline Percent of population with private health insurance [5] & $\begin{array}{l}27.9 \\
\text { North (13.3\%); Northeast (15.5\%); South (32.8\%); Southeast } \\
(36.9 \%) ; \text { Midwest (30.4\%) }\end{array}$ \\
\hline
\end{tabular}

ease of access or their ability to pay [7]. About $71 \%$ of the population relies on SUS almost exclusively [5].

The Brazilian Constitution of 1988 recognized healthcare as a right of the population, thereby creating SUS, governed by doctrinal organizational principles (Table 2) [8]. Funding for SUS is provided through taxes and social contributions at the federal, state, and municipal levels. Historically, the main financier of SUS is the federal government.

Primary care is the preferred point of entry to SUS, aiming to provide universal access and comprehensive services. It coordinates and expands cover to more complex levels of care, as well as implementing cross-sector programs like health promotion and disease prevention. This is done by using organizational strategies such as the Community Health Workers Program and the Family Health Strategy [9]. About $48 \%$ of SUS users have primary care as their go-to service [5].

Secondary and tertiary care is provided by specialized services in outpatient clinics and hospitals, using intermediate and high-level technology. These levels of care include specialized services for diagnostic and therapeutic support, emergency care, and private and university hospitals under contract to SUS [9]. SUS is a referral system. With technical and financial support from state and federal levels, each municipality is responsible for providing care to its population or, when lacking the services needed, refer users to other municipalities offering that service. Referral and referral-back are agreed between the municipalities [6].

The delivery of quality healthcare services is affected by Brazil's large size, socio-economic contrasts, and uneven distribution of resources. These factors influence the effectiveness of hearing healthcare provided by SUS. This paper describes the milestones in the development of hearing healthcare public policies in Brazil, as well as outlining some of the challenges faced by the system. The provision of health-related services at a distance (telehealth) has the potential to meet some of these challenges, and so the main concepts behind the implementation of the Brazilian Telehealth Networks Program will be discussed. In this context, the results and implications of research on remote hearing aid fitting, conducted at Bauru Dental School, will also be presented.

\section{Service provision for people with hearing impairment under SUS}

It is estimated that $6.8 \%$ of the Brazilian population (approximately 13.9 million) have a disabling hearing impairment (5.4\% moderate, $1.2 \%$ severe, and $0.2 \%$ profound), thus requiring intervention. The groups at higher risk for hearing loss are men, people over 60 years old, and those with lower education and income [10]. Although they are available on the private market, the high cost of hearing aids and cochlear implants (CIs) makes their purchase prohibitive for the vast majority of the population. 
Table 2. Doctrinal and organizational principles of SUS [8]

\begin{tabular}{|c|c|}
\hline \multicolumn{2}{|l|}{ Doctrinal principles } \\
\hline Universality & $\begin{array}{l}\text { Universal access for all citizens to health services at all health care levels. Healthcare is } \\
\text { a right of every citizen and a duty of the federal, state, and municipal governments }\end{array}$ \\
\hline Equity & $\begin{array}{l}\text { To ensure programs and services at all levels, according to the complexity required in } \\
\text { each case }\end{array}$ \\
\hline Integrality & $\begin{array}{l}\text { It is the recognition that each person is an indivisible whole and part of a community. } \\
\text { The service provision, with their varying degrees of complexity, form a system capable } \\
\text { of providing comprehensive care }\end{array}$ \\
\hline \multicolumn{2}{|l|}{ Organizational principles } \\
\hline Hierarchy & $\begin{array}{l}\text { Services are organized in levels of increasing technological complexity, arranged in a } \\
\text { defined geographical area }\end{array}$ \\
\hline Decentralization & $\begin{array}{l}\text { The management, formulation, and implementation of policies are the responsibility of } \\
\text { federal, state, and municipal governments }\end{array}$ \\
\hline Solvability & $\begin{array}{l}\text { When health assistance is needed, the corresponding service must be able to face it } \\
\text { and solve it to the level of their competence }\end{array}$ \\
\hline Social participation & $\begin{array}{l}\text { Through their representative organizations, people participate in the formulation of } \\
\text { health policies and control of its implementation, at all levels }\end{array}$ \\
\hline $\begin{array}{l}\text { Complementarity of the private } \\
\text { sector }\end{array}$ & $\begin{array}{l}\text { When the public sector is insufficient, private services are contracted to complement } \\
\text { the care network }\end{array}$ \\
\hline
\end{tabular}

Hearing healthcare services were incorporated into SUS in 1993, including the provision of CIs [11]. Subsequently, in 1996 and 1999 [12], standards and criteria for CI surgery were set. In 1998, the first regulations for outpatient services were published [13], including auditory diagnosis, hearing aid fitting, and follow up. Although outpatient services are of major importance in enabling the provision of hearing healthcare to the population, analysis of outpatient services statistics show an emphasis on diagnostic procedures and hearing aid dispensing. Comprehensive care is not granted, as hearing healthcare given by primary care providers is only occasionally performed, as are speech and hearing therapies [14].

Given this situation, in 2004 the Ministry of Health established the National Policy of Attention to Hearing Health (PNASA, in Portuguese), including the provision, at different levels of care and in all life cycles, of audiological services ranging from hearing health promotion to auditory rehabilitation [15]. Along with PNASA, another body, the "States' Networks for Hearing Health Services" was created $[16,17]$. Another major breakthrough for children's hearing health was the publication in 2010 of Federal Law 12303 [18] which made newborn hearing screening mandatory.

PNASA has made significant progress. In the period of 2005-10, there was an increase from 39 to 143 in the number of public hearing healthcare facilities in Brazil [19]. In addition, there has been a considerable increase in the number of audiological procedures performed throughout the country such as otoacoustic emissions, auditory brainstem responses, pure tone audiometry, immittance measures [20,21], and hearing aid selection and fitting [21]. A gradual increase was observed in the number of speech-language and hearing therapies that, although still not sufficient, suggests there has been a reorganization of the networks so that they can now offer such services [19].
However, implementation of PNASA has occurred unevenly among the states and municipalities. Major inequalities in access to care have been noted, mainly in the North and Midwest [20]. Particularly in the North, Northeast, and Midwest, actions fall short of the real needs of people with hearing impairments, especially in terms of covering high-cost and complex procedures and auditory rehabilitation [22]. An analysis of 95 hearing healthcare facilities showed that $9 \%$ had a shortage of audiologists and $58 \%$ had long waiting lists for access to diagnosis and treatment [23].

Furthermore, good practice standards for hearing aid selection and fitting were not being followed in all services, as real ear measures were only used in $21 \%$ of verification procedures. There was also a discrepancy between the number of hearing aids dispensed and the number of follow-up services reported - meaning perhaps that those services were not being offered and/or patients were not being followed up with treatment [19].

By 2011, the provision of care for people with disabilities faced significant constraints: fragmentation of care providers, focus on specialized care, implementation of services on the basis of population numbers alone, and lack of monitoring and assessment mechanisms other than those centered just on production metrics [see paper by Vera Lúcia Ferreira Mendes, Coordinator of the Technical Area of Health for People with Disabilities, Ministry of Health: "National Plan of Rights for People with Disabilities", $6^{\text {th }}$ Brazilian Congress of Telemedicine and Telehealth, São Paulo, November 2013.] In order to implement new initiatives and further drive actions already deployed, the "National Plan of Rights of Persons with Disabilities" was launched in 2011 [24], aiming to improve access for people with disabilities to basic rights such as education, 


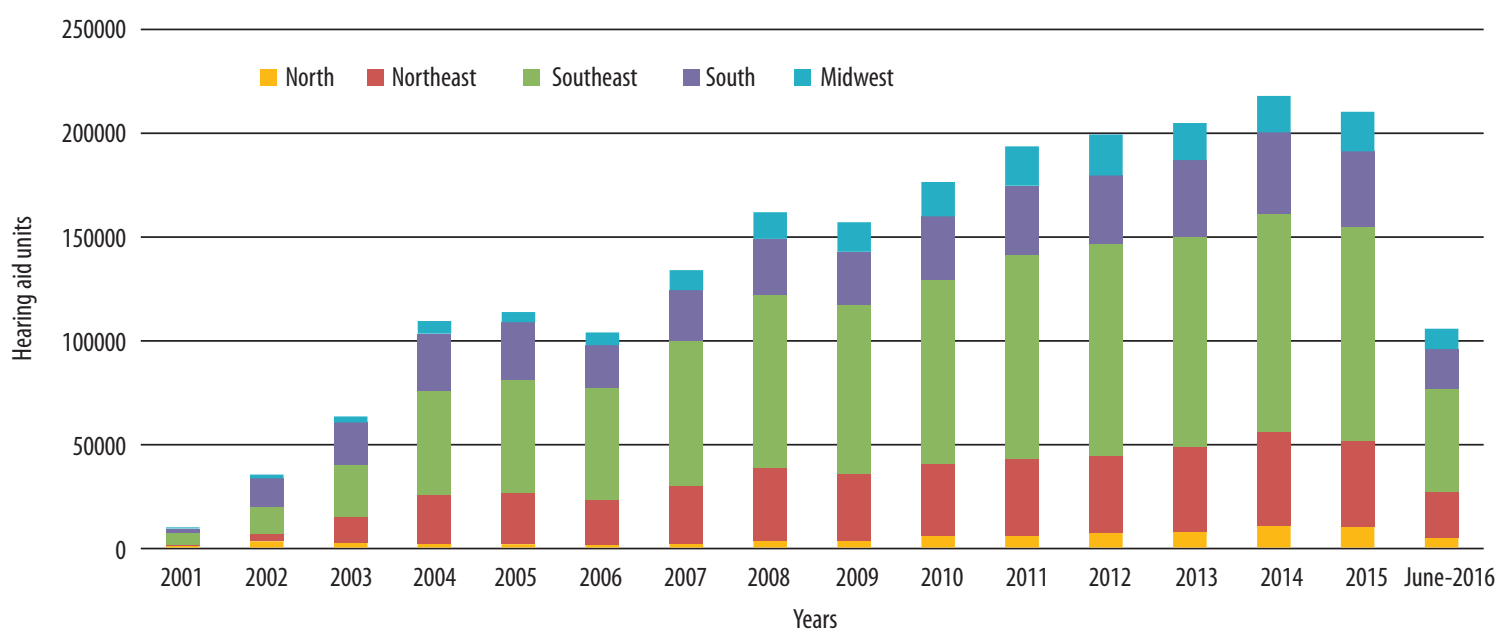

Figure 1. Hearing aids dispensed by year and region. Source: Brazilian Ministry of Health. SUS Outpatient Information System (SIA/SUS). [Accessed 2016 Sep 15; available at: http://www.datasus.gov.br]

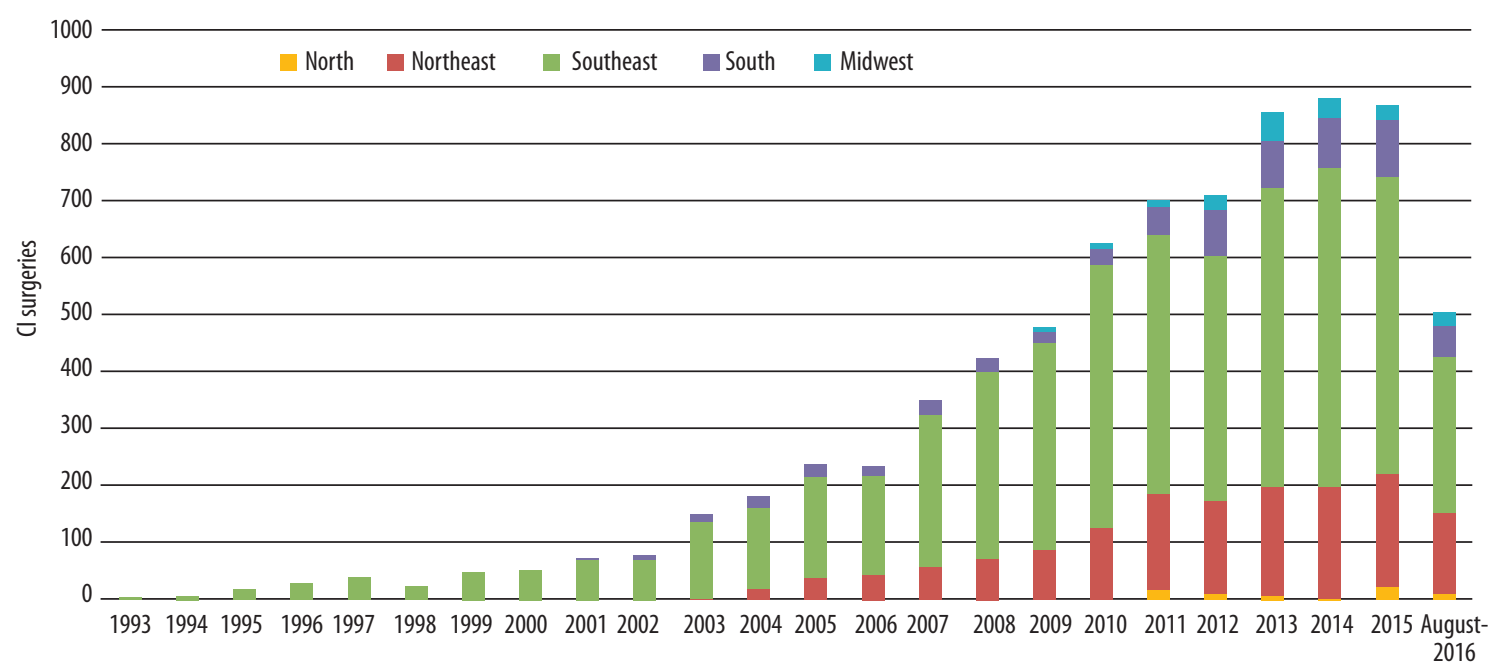

Figure 2. Cochlear implant surgeries by year and region. Source: Brazilian Ministry of Health. SUS Hospital Information System (SIH/SUS). [Accessed 2016 Sep 15; available at: http://www.datasus.gov.br]

transport, labor markets, vocational training, housing, and healthcare.

In 2012 PNASA was revoked and the "Network of Care for People with Disabilities" was created under SUS [25] for implementation, qualification, and monitoring of rehabilitation actions in the states and municipalities. This Network is organized into components of primary care, specialized care in rehabilitation (e.g. auditory, physical, intellectual, visual, and multiple disabilities), as well as hospital and emergency care. In terms of accessibility, another important achievement occurred in 2013, when SUS began dispensing frequency/digital modulation systems for people with hearing impairments [26].

In brief, during the last 28 years Brazil has implemented one of the largest universal healthcare systems in the world, obtaining impressive results: increased access to healthcare for a substantial proportion of the population, universal coverage of vaccination and prenatal care, increase in life expectancy, and decrease in child mortality, among others [7].

Over the years, SUS has also significantly improved the care of people with hearing impairments. As an example of SUS's investment in hearing healthcare, from 2000 up to June 2016, 2,201,396 hearing aids were dispensed by this system (Figure 1), equal to $54.6 \%$ of the total number of hearing aids imported in Brazil in the same period (according to Ministry of Industry, Foreign Trade and Services, Analysis System of Foreign Trade Information, available at http://aliceweb.mdic.gov.br). In addition, 7582 cochlear implant surgeries were performed (Figure 2). However, as part of SUS, public hearing healthcare is also afflicted by complex challenges while striving to keep to its principles.

Currently, SUS has 27 CI programs, 131 hearing healthcare clinics, and 69 specialized rehabilitation centers servicing people with hearing impairments. Based on the prevalence of disabling hearing losses in Brazil [10], there 


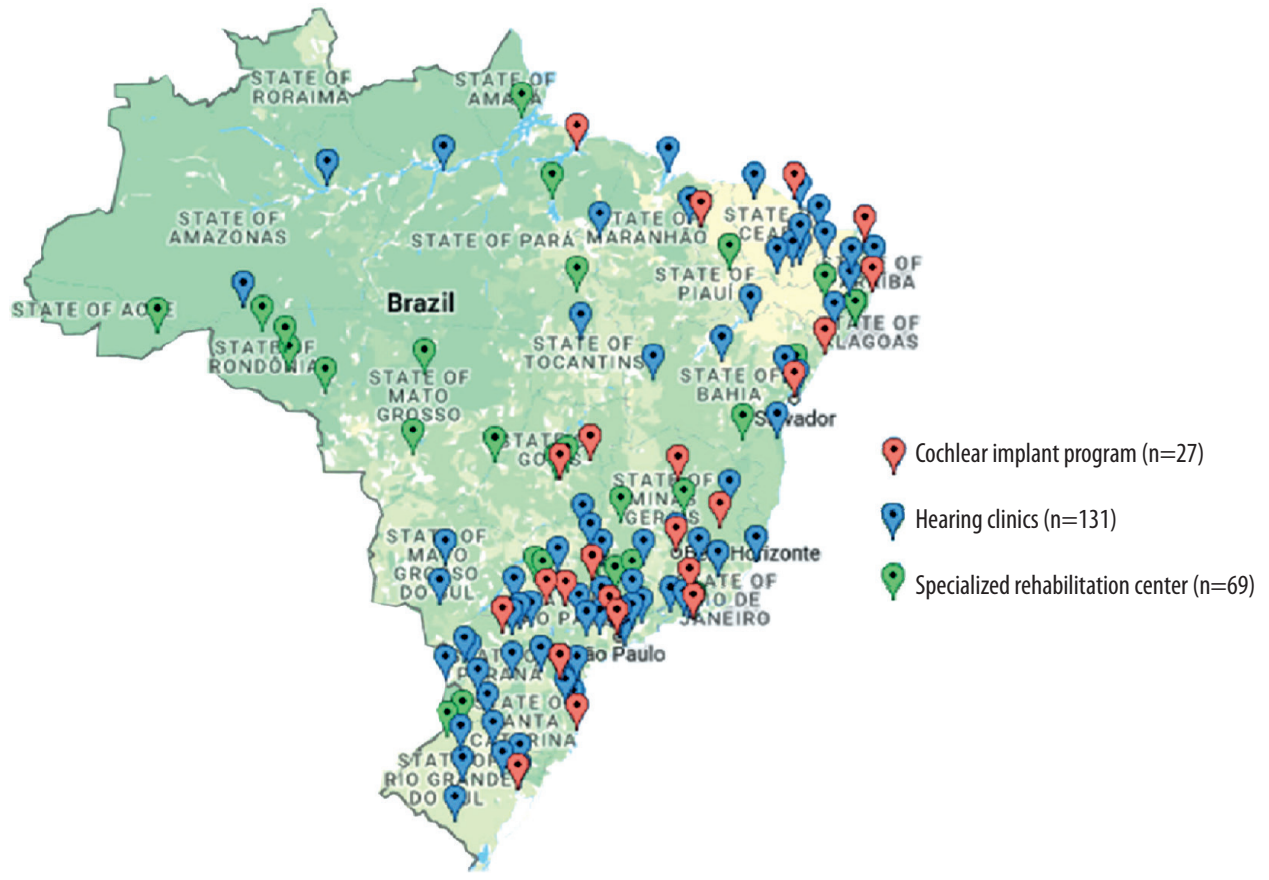

Figure 3. Hearing healthcare facilities in Brazil. Source: Brazilian Ministry of Health. National Register of Healthcare Facilities (CNES). [Accessed 2016 Sep 15; available at http://www.cnes.datasus.gov.br]

are approximately 13.4 million potential hearing aid candidates and, conservatively, 408,000 CI candidates - a demand already beyond SUS capacity. Despite governmental efforts to expand the system and address disparities in distribution of hearing healthcare services, differences in coverage among regions are still present (Figure 3 ).

As a referral system, the network of services for people with disabilities, and its points of attention in each health region, need to be carefully organized and provided with physical structures and properly trained teams. The delivery of assistance needs to be done in close coordination with other points of attention [27]. However, in order to optimize the operation of the system, its organization of referral (and referral-back), is still one of the major challenges to be addressed [19].

The costs of patient transportation and housing to obtain treatment in other regions burden SUS and overload services mainly at secondary and tertiary care. Patients also face the risks inherent to traveling as well as expenditure of time and, in many cases, loss of wages. An even greater difficulty is posed for families with young children, the elderly, people with debilitating diseases, or people with special needs who require special care [28]. In fact, a study carried out in the state of Sao Paulo showed that, after hearing aid fitting, a high rate of absenteeism at follow-up consultations could be due to these factors. Additionally, a significant proportion of these patients were not wearing the devices frequently (or not at all) - mainly due to problems that could be solved by a follow-up appointment [29]. This situation challenges the cost-effectiveness of the system.
The shortage of well-trained audiology professionals, especially in remote areas of the country, is another aspect that must be considered. This is a global phenomenon an analysis of 62 countries has shown that $86 \%$ of them do not have enough professionals to meet demand [30]. Due to increases in populations as well as demographic changes, the need for hearing healthcare services will grow over the next 30 years. In the United States, in order to meet demand, the number of people entering the field of audiology will have to increase by $50 \%$, beginning immediately [31].

As for other health professions, the entry level for the audiology profession in Brazil is the baccalaureate degree. At least 4 years are required for the completion of coursework, which involves, among other studies, speech-language pathology, audiology, voice, and oral myology. Dual-certification (SLP-Audiology) is granted to those who successfully complete the program and they are free to work in any area of the field $[32,33]$.

Although public health programs in Brazil rely on generalists, there is a need for professionals with more specific training in the area of audiology, particularly since 2004, when PNASA was established [33]. However, the concentration of training programs in the Southeast and South of the country hinders continuing professional education. This, in turn, leads to an uneven distribution of qualified professionals across the country. As of August 2016, there were 39,870 SLP-Audiologists in Brazil, 2,191 of them being specialized in Audiology, and about 70\% of these specialists were located in the Southeast region (Conselho Federal de Fonoaudiologia, 2016. Especialistas por área. http://www.fonoaudiologia.org.br/cffa/index.php/ especialista-por-area/). 
Obsolete or malfunctioning equipment at hearing healthcare clinics - or even the total lack of it - affects the quality of the care provided. In addition, a multidisciplinary team is required at hearing healthcare facilities. However, a fragmented and reductionist approach to care is typically observed instead of a comprehensive one [34]. Further, the public sector requires tenders to be submitted for the purchase of services and goods; particularly for the acquisition of hearing devices, the procedure can be highly bureaucratic and time-consuming, leading to waiting lists and affecting the timeliness of treatment.

Quality assessments conducted by SUS auditors focus on infrastructural and quantitative aspects - the condition of facilities, the number of professionals, available equipment, and the number of audiological procedures provided and of hearing aids fitted. These assessments do not take into account the whole gamut of resources needed to ensure that quality hearing healthcare is being provided [14]. Auditors are not required to have a hearing healthcare background, further limiting the scope of an audit.

Although SUS has a budget of around 60 billion dollars (approximately $3.6 \%$ of GDP), the system is chronically underfunded [7]. Recently, problems in Brazil's healthcare system have been exacerbated by economic recession and political turmoil. Governments at national, state, and municipal levels have enforced austerity measures, and so cuts to healthcare budgets are expected [35]. Different approaches - such as telehealth - are needed in order to mitigate these shortcomings.

\section{Telehealth: General concepts}

Nowadays, making high quality healthcare services accessible to all is one of the main issues faced by policy makers, researchers, health professionals, and of course, patients and their families. The path to reach this goal is complicated and difficult. Seemingly unsolvable problems - poverty, conflict, humanitarian emergencies, infectious disease, and inequality - stand in the way of achieving higher levels of health, and add to acceleration of costs, global aging, and an increase in chronic diseases [36,37].

According to the World Report on Disability [38], obstacles to obtaining quality healthcare are even greater for people with disabilities, involving attitudinal, physical, and systemic factors. The factors interact and hinder health care access, in this way making change necessary across virtually all components of the health care system. Among other strategies, the World Report suggests exploring the use of information and communication technologies (telehealth) to improve services, capacity, and access to information for people with disabilities.

The Greek prefix 'tele' means 'at a distance', and so telehealth means 'health at a distance. The World Health Organization uses the broad definition of telehealth as the provision of healthcare services at a distance, by different professionals, via information and communication technologies (ICT), to perform diagnosis, treatment, and prevention of diseases, for research and evaluation, as well as for continuing the education of health professionals - all in the interest of promoting health for individuals and their communities [39].

The development of ICT and its increasing application to different healthcare contexts has led to the emergence of different terms such as telehealth, telemedicine, telecare, telepractice, e-health, and, more recently, mobile health (m-health). The latter was introduced in response to the ubiquity and expanded capabilities of mobile communication devices [40]. M-health is defined as health practice supported by mobile devices such as mobile phones, patient monitoring devices, personal digital assistants, and other wireless devices [41]. In the literature the terms telehealth, telemedicine, e-health, and $\mathrm{m}$-health are often used interchangeably [37], and since there is no single universally accepted definition they are here used synonymously.

Telehealth has been recognized as an alternative to improve healthcare in developing countries, sparsely populated areas, and areas with limited access to either primary or specialized care. Telehealth can increase the efficiency of an existing service: it can improve the vertical and horizontal communication between levels of care, promote education, and facilitate the prioritization and decentralization of services. In remote or isolated areas telehealth can have an even greater impact, allowing (among other opportunities) health care to be offered which was previously non-existent [36]. Furthermore, $\mathrm{m}$-health applications are multiplying quickly, being especially suitable for person-centered activities [37,40].

Telehealth services can be delivered via different models: - Synchronous: interaction between an individual (patient, caregiver, or professional) and the person providing service occurs in real time, typically via interactive video. Remote control of computer applications can also be employed [42].

- Asynchronous (store and forward): there is no real time interaction between the parties. Instead, relevant information is recorded in the form of texts, audio, video clips, or still images, and transmitted to the person providing the service via secure media (e.g. e-mail, electronic forms) [42].

- Hybrid: uses a combination of synchronous and asynchronous technologies [42].

- Self-testing: instruments provided to patients for selfassessment or care [43]. For example, hearing screening conducted online via questionnaires or an online hearing test via some form of automated procedure.

- Telemonitoring: health data is acquired at the patient's site (e.g. home) via electronic devices (e.g. transducers, internet-ready devices) and transmitted to a healthcare provider. This model allows for remote monitoring of health data, timely intervention, and delivery of some form of feedback.

These different models have pros and cons and the choice of one over the other is based on the population's needs to be met, the goals to be obtained with the service offered and the availability of budget and infrastructure. Different issues arise for the provision of audiology via telehealth: the technology, the professionals' skills, ethics (e.g. safety, privacy, and confidentiality), reimbursement, and technology accessibility and usability for people with hearing 
loss. The in-depth discussion of each of these factors, and others, is beyond the scope of this paper.

To determine the required technological infrastructure, one needs to consider the clinical requirements, the nature of the interaction, and the information to be transmitted between the parties in teleconsultation. For instance, the required infrastructure differs vastly between synchronous and asynchronous models. In an asynchronous approach, real time interaction does not occur so scope is usually prioritized over technological requirements. However, during an asynchronous consultation, a myriad of activities can be carried out - provision of second opinions, clinical reports, guidelines for treatment, and so on, but situations demanding an immediate response impose limits to this model. In contrast, a synchronous approach enables real time interaction between the participants, emulating a face-to-face encounter, which is particularly suitable for handling time-critical issues. Despite improvements in videoconference and remote desktop applications, the availability of the internet bandwidth required may be a barrier to implementing this model (especially in developing countries where broadband connection is not always available or affordable).

Whenever people with hearing impairments are involved, the audio and video bandwidth requirements for synchronous implementation must be strengthened, as such people are more likely to be affected by audio/video distortions and delays. Careful consideration of room acoustics, lighting, and camera placement is needed to ensure good audio and visual cues. Regardless of the selected model, the healthcare provider must also be entirely familiar with the equipment, remaining in control so that the focus remains on the clinical and/or educational aspects of the telehealth encounter. This also applies to facilitators who may take part in this encounter, who must be adequately trained to assist with audiological procedures at the patient's end (e.g. positioning headphones on the patient's ears, placing electrodes, etc.).

The use of telehealth does not preclude conforming with ethical and regulatory requirements already in place, such as safety, confidentiality, and effectiveness. In Brazil, the Federal Council of Speech Language Pathology and Audiology (CFFa, in Portuguese) approved in 2009 the first regulation regarding the use of telehealth in this area, and resolution CFFa 427, published in 2013, is now in effect [44]. Among other provisions, it describes services that can be offered via telehealth and ensures they are conducted in an equivalent way to face-to-face procedures.

The current regulatory framework is still controversial. The use of teleconsultation for clinical evaluation, diagnosis, or therapeutic prescription - without another SLPAudiologist being present with the patient - is not allowed (except for research purposes). Such a prohibition creates a paradox, since the prime purpose of telehealth is to enable access where and when such professionals are lacking. The issue is complex, and has been discussed in the CFFa's Telehealth Working Group as well as in the "Telehealth in Audiology" forums held annually by the Brazilian Academy of Audiology.

\section{Telehealth Brazil Networks Program}

The first experiences of telehealth in Brazil occurred in the early 1990's, in the public and private sectors as well as in universities. These initiatives were autonomous and decentralized, with specific aims relating to the needs of each institution. There was an increase in activity in the late 1990's, and by the turn of the decade telehealth projects began to spread across the country. Up to this point, the federal government had only adopted tentative measures to encourage telehealth [45].

From 2004 on, there was an important evolution of telehealth in Brazil, with incentives from research funding agencies and government actions that made possible research teams in different universities to be established. Of particular relevance was the launching in 2005 of the public research notice "Institutes for the Millennium", by the federal government's National Council for Scientific and Technological Development (CNPq in Portuguese). This notice offered telehealth as an inducement, meaning that $\mathrm{CNPq}$ considered it a strategic research area. Also in that year, the 'Digital Medical Station Project' received a grant from $\mathrm{CNPq}$ to form a consortium of nine institutions to expand and consolidate telehealth in Brazil. For this purpose, electronic tutoring environments and virtual clinics were created, the emergence of new telehealth centers was fostered, and training was promoted in different institutions and government agencies such as the Ministry of Health (MoH) [46].

Telehealth initiatives around the country triggered important public policy building processes. In 2006, the $\mathrm{MoH}$ created a Permanent Telehealth Commission, bringing together various ministries, federal government agencies, university representatives with experience in telehealth, and scientific societies to share knowledge and plan a cooperative strategy for the implementation and development of telehealth in Brazil [47]. Also in 2006, the Ministry of Science, Technology and Innovation launched the University Telemedicine Network to build ICT infrastructure to connect public universities and their hospitals, as well as certified education and research hospitals, for fostering telehealth activities.

Experience in Brazil has shown that investment in primary care, involving training of family health professionals and community workers, has led to significant improvements in healthcare systems as well as a reduction in their cost [48]. In 2007, the "Telehealth Brazil Program - Pilot Project" was established for developing actions to support healthcare and, mostly, the continuing education of professionals for primary care [49]. This inter-ministry program involved federal, state, and municipal governments as well as academic institutions. Nine "Telehealth Centers" were created at universities in nine different states, which were connected to 100 telehealth points at primary care level, distributed over each state. These 900 points received ICT infrastructure needed to participate in the project [50]. The main strategy involved knowledge-sharing between telehealth centers in order to improve training and decrease the turnover of professionals in remote areas, lessening their feelings of isolation, and reducing the amount of unnecessary patient referral to other levels of care [48]. 
Table 3. Main ordinances related to the implementation of the Telehealth Program under the Unified Health System

\begin{tabular}{|c|c|}
\hline Year & Description \\
\hline 2006 & $\begin{array}{l}\text { Ordinance \#561: Creation of the Telehealth Permanent Committee at the Ministry of Health, with representatives } \\
\text { of several institutions, universities, and ministries (revoked by Ordinance 452) }\end{array}$ \\
\hline 2007 & $\begin{array}{l}\text { Ordinance \#35: Establishment of the "Telehealth Brazil Program" with the aim of developing actions to support } \\
\text { healthcare and continuing education for the Family Health Strategy }\end{array}$ \\
\hline 2010 & $\begin{array}{l}\text { Ordinance \#402: Nationwide establishment of the "Telehealth Brazil Program" to support the Family Health } \\
\text { Strategy under SUS (revoked by Ordinance 2.546) }\end{array}$ \\
\hline 2010 & Ordinance \#452: Creation of the Telehealth Permanent Committee at the Ministry of Health \\
\hline 2011 & $\begin{array}{l}\text { Ordinance \#2.073: Regulation of the use of interoperability and health information standards for health } \\
\text { information systems under SUS, private sector and supplemental healthcare }\end{array}$ \\
\hline 2011 & $\begin{array}{l}\text { Ordinance \#2.546: Redefines and expands the Telehealth Brazil Program, now called "National Program Brazil } \\
\text { Telehealth Networks" }\end{array}$ \\
\hline 2011 & $\begin{array}{l}\text { Ordinance \#2.554: Institutes, in the Requalification Program for Basic Health Units, the informatics and Telehealth } \\
\text { Brazil Networks in Primary Care components, integrated into the Telehealth Brazil Networks }\end{array}$ \\
\hline 2012 & $\begin{array}{l}\text { Ordinance \#2.013: Establishes the Working Group to evaluate, discuss, and propose criteria and actions for } \\
\text { expansion of the Telehealth Brazil Networks }\end{array}$ \\
\hline 2014 & Technical Note \#63: Guidelines for the preparation and submission of Formative Second Opinions \\
\hline
\end{tabular}

Based on the results of the pilot project, the Telehealth Brazil Program was established nationwide in 2010, in order to strengthen the Family Health Strategy and increase the resolution of cases via the provision of formative second opinion (FSO) and other activities [51]. FSO is a systematic response, based on the review of the best scientific and clinical evidence, to questions originating from teleconsultations, selected according to their relevance to SUS guidelines. Unlike a simple response to a question, the FSO focuses on the transmission of knowledge for the construction of reasoning. It integrates educational concepts such as problem-based learning, evidence-based health, distance preceptorship, and support. The syntheses of such interactions can be transformed by instructional designers into knowledge units, which help in contextualized guidance for decision-making [52].

The "Virtual Library in Primary Health Care", in operation since 2007, was a product of technical cooperation between the Latin American and Caribbean Center of Information in Health Sciences (BIREME, PAHO/WHO) and the $\mathrm{MoH}$, in partnership with the institutions participating in the Telehealth Brazil Program. Among other activities, it provides support for FSO and the development of educational content based on current scientific knowledge that is relevant and applicable to primary care.

From 2008 to 2011, 56,075 teleconsultations and 416,691 procedures were carried out at the Telehealth Brazil Program. Besides, 643 FSOs were available on the Program's website. In places where second opinions were offered, unnecessary patient referral to other levels of care was avoided in $70-80 \%$ of cases. For each case solved without the need for referral, there was a saving equivalent to five times the cost of specialized care that would have been otherwise provided - especially in the Amazon region, where transport is costly [50].
Due to favorable results, in 2011 the program was redefined, expanded, and renamed as "Telehealth Brazil Networks" [53]. The network is comprised of technical/ scientific telehealth centers (educational or management institutions as well as healthcare services responsible for providing and administering telehealth services) and telehealth points (public healthcare facilities where professionals can ask for telehealth services). In parallel, the IT and "Telehealth Brazil Networks in Primary Care" components were established [54] to guarantee connectivity to basic healthcare units.

Telehealth Brazil Networks also has the potential to promote changes in the work process in specialized care, as those teams are required to perform other activities such as teleconsultations, remote diagnosis, case discussions, and networking with other levels of care - thus helping them to commit to comprehensive care [55].

Telehealth is a strategic action that, in addition to improving the quality and optimizing healthcare, allows for rationalization of available resources. The $\mathrm{MoH}$ has focused on expanding telehealth activities in the country and, in 2012, established a working group for the assessment, discussion, and proposal of criteria and actions for expanding the Telehealth Brazil Networks [56].

Currently, the program is operating in 22 states, bringing together nearly 6200 telehealth points in basic health units, covering 2600 municipalities (see Telessaúde Brasil Redes, Mapa Situacional, 2015, http://portalsaude.saude.gov.br/images/jpg/2015/fevereiro/12/mapa-situacional-2015.jpg). Interviews carried out with 29,778 teams in basic healthcare units, in different Brazilian states, showed that $50 \%$ of them had internet connection. Only $13.9 \%$ of teams had electronic medical records; where implemented, $80.7 \%$ of these were integrated with other points in the network. Additionally, $30.8 \%$ of teams reported using 


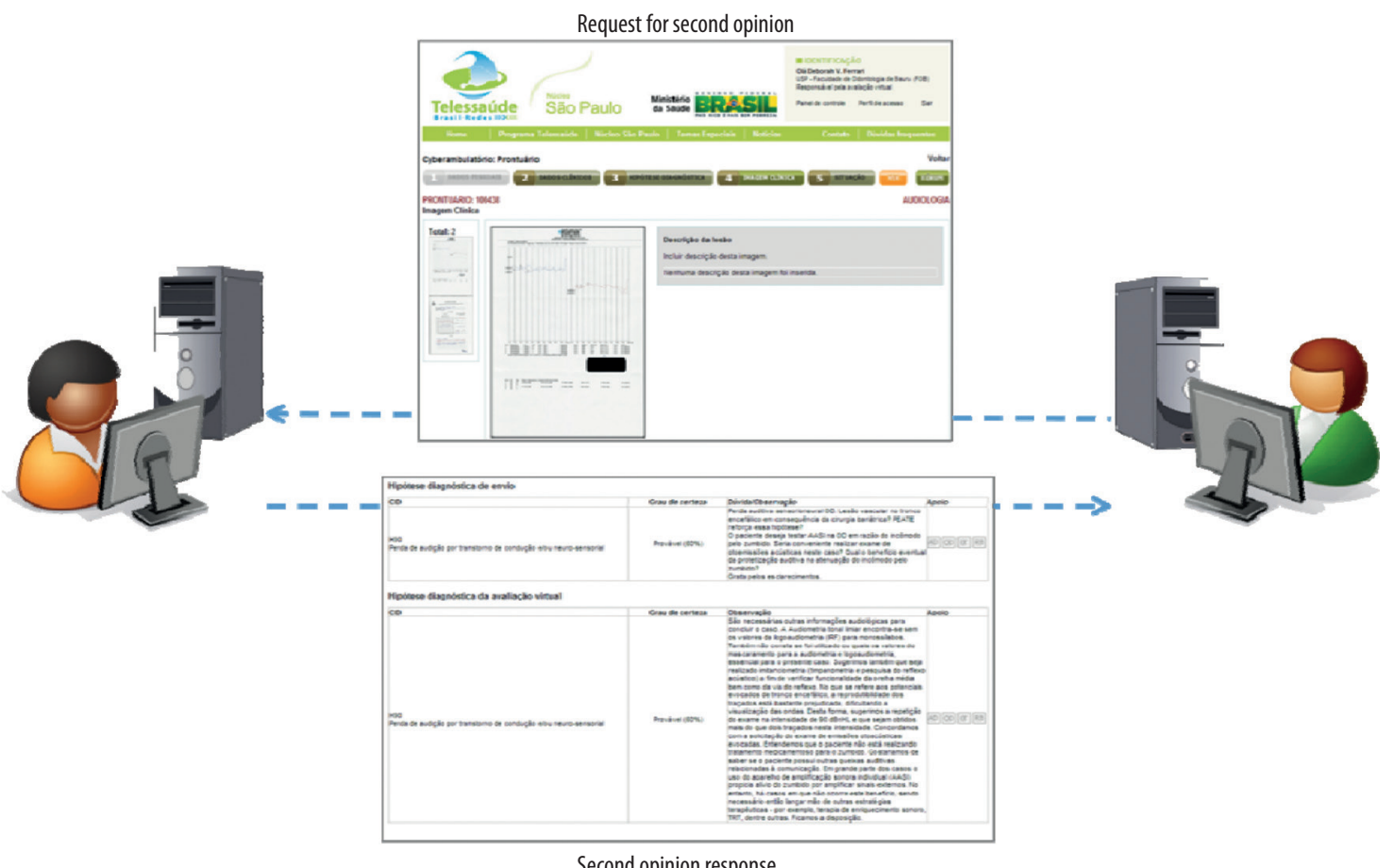

Figure 4. Representation of asynchronous teleconsultation with the use of Cyberambulatory

Remote site

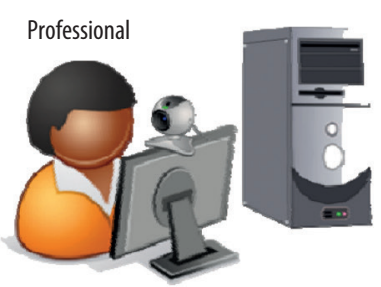

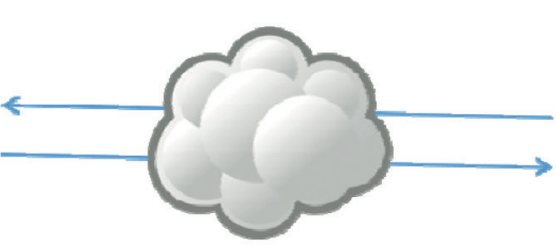

Real time data, audio and video transmission
Test site

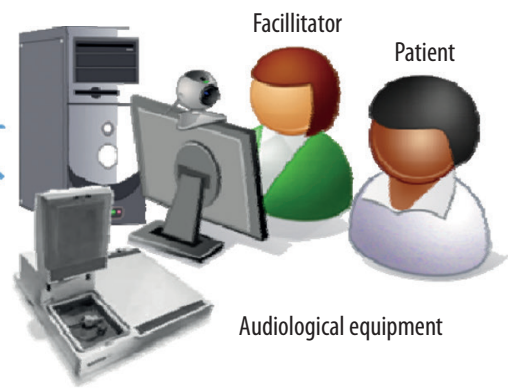

Figure 5. Representation of synchronous teleconsultation with remote control of audiological equipment

telehealth for other activities, including remote diagnosis and continuing education [57].

\section{Teleconsultations for hearing aid programming and fitting}

The Speech Language Pathology and Audiology Department at Bauru School of Dentistry (BSD), University of Sao Paulo (USP), has been involved with telehealth activities since the late 1990's, starting with distance learning. A major milestone was BSD's participation in the "Digital Medical Station Project", coordinated by the Discipline of Telehealth at USP's School of Medicine (DTM-USP). This enabled the development of the required infrastructure and human resources, enhancing BSD's capabilities in this field and served as the foundation for the role it played in the MoH's Telehealth Brazil Project - Sao Paulo Center, also coordinated by DTM-USP, during the period
2007-12. Among other activities within this project, different instructional materials were developed aiming to support primary care professionals in performing preventive actions and increasing awareness for communication disorders in their communities.

Additionally, asynchronous remote second opinions were provided for healthcare professionals through the Cyberambulatorio platform. With this platform, a primary care professional was able to submit, with the patient's consent, the case history, test results, and a preliminary hypothesis or clinical assessment to be remotely analyzed and fed back to the originator. The professional delivering the second opinion could also provide links to related instructional materials available from this platform (Figure 4).

Research on audiological teleconsultations began in 2003, starting out as a proof of concept for hearing aid 
programming and verification by means of remote desktop sharing and control (Figure 5).

In essence, a facilitator at the test site inserts a probe tube and hearing aid in the patient's ear canal. The programming interface and the real ear equipment are connected to an internet-ready computer, which is remotely controlled in real time by an audiologist using desktop-sharing/ controlling software. With a webcam and interactive audio and video, the remote audiologist communicates with the patient and the facilitator while programming, adjusting, and verifying the hearing aid. For privacy and confidentiality, data is encrypted.

Summarized in Table 4 are other subsequent research activities assessing synchronous teleconsultations with

Table 4. Summary of research on teleconsultations for hearing aid fitting conducted at Bauru Dental School, USP

\begin{tabular}{|c|c|c|c|c|c|}
\hline $\begin{array}{l}\text { Reference/ } \\
\text { Design }\end{array}$ & Purpose & Participants & Interactive video & Main outcome measures & Comments \\
\hline $\begin{array}{l}\text { Ferrari, } \\
2006[58] \\
\text { RCT }\end{array}$ & $\begin{array}{l}\text { Hearing aid } \\
\text { programming } \\
\text { and verification } \\
\text { efficacy }\end{array}$ & $\begin{array}{l}n=30 \\
\text { Mild-to-severe } \\
\text { sensorineural } \\
\text { bilateral HL } \\
\text { F-F group ( } n=15) \\
9 \text { men, } 6 \text { women } \\
\text { Age 44-75 yrs ( } 60 \\
\text { yrs) } \\
\text { Teleconsultation } \\
\text { group ( } n=15 \text { ) } \\
10 \text { men, } 5 \text { women } \\
\text { Age 44-75 yrs ( } 61 \\
\text { yrs) } \\
\text { Facilitator: } 5 \text { SLP- } \\
\text { Audiologists without } \\
\text { HA experience }\end{array}$ & $\begin{array}{l}\text { NetMeeting } \\
\text { software } \\
\text { LAN } 10 \text { Mbps. } \\
\text { Connection } \\
\text { speed } 384 \\
\text { kbps }\end{array}$ & $\begin{array}{l}\text { Duration: Teleconsultation } 2 \text { minutes } \\
\text { shorter than F-F (3\% decrease) } \\
\text { Patients } \\
\text { 20-item questionnaire regarding } \\
\text { quality of consultation. Closed } \\
\text { responses pn a 5-point Likert-type } \\
\text { scale } \\
\text { No difference between F-F and } \\
\text { teleconsultation: interaction and } \\
\text { communication with the professional, } \\
\text { confidence in the procedure, received } \\
\text { information } \\
\text { Facilitators } \\
\text { 20-item questionnaire regarding } \\
\text { learning. Closed responses on a 5-point } \\
\text { Likert-type scale } \\
\text { Teleconsultation helped learning of } \\
\text { hearing aid related concepts and } \\
\text { procedures }\end{array}$ & $\begin{array}{l}\text { Sporadic } \\
\text { acoustic } \\
\text { feedback at } \\
\text { the patient's } \\
\text { site, making } \\
\text { professional- } \\
\text { patient } \\
\text { interaction } \\
\text { difficult }\end{array}$ \\
\hline $\begin{array}{l}\text { Ferrari \& } \\
\text { Bernardez- } \\
\text { Braga, } \\
2009 \text { [59] } \\
\text { Repeated } \\
\text { measures }\end{array}$ & $\begin{array}{l}\text { Feasibility of } \\
\text { remote real ear } \\
\text { measurements }\end{array}$ & $\begin{array}{l}n=60 \text { hearing aid } \\
\text { users (105 ears) } \\
\text { Age } 18-84 \text { yrs ( } 67 \\
\text { yrs) } \\
\text { Facilitator: SLP- } \\
\text { Audiologists without } \\
\text { HA experience }\end{array}$ & $\begin{array}{l}\text { Polycom PVX } \\
\text { v8.0 software } \\
\text { LAN } 10 \text { Mbps. } \\
\text { Connection } \\
\text { speed } 384 \\
\text { kbps }\end{array}$ & $\begin{array}{l}\text { Mean difference F-F and } \\
\text { Teleconsultation REUR, REAR, and REIG: } \\
0 \text { to } 2.2 \mathrm{~dB}(p<0.05) \text {. Not clinically } \\
\text { significant } \\
\text { Pearson correlations REUR, REAR, and } \\
\text { REIG }=0.72-0.95\end{array}$ & \\
\hline $\begin{array}{l}\text { Campos } \\
\text { \& Ferrari, } \\
2012[60] \\
\text { RCT }\end{array}$ & $\begin{array}{l}\text { Efficacy of remote } \\
\text { hearing aid fitting }\end{array}$ & $\begin{array}{l}n=50 \\
\text { Mild to severe } \\
\text { sensorineural } \\
\text { bilateral HL } \\
\text { F-F group }(n=25) \\
\text { Age } \bar{\chi} 69.6 \text { yrs } \\
\bar{\chi} \text { hearing threshold } \\
50.2 \mathrm{~dB} \text { HL } \\
\text { Teleconsultation } \\
\text { group ( } n=25) \text { : } \\
\text { Age } \bar{\chi} 70.4 \text { yrs } \\
\bar{\chi} \text { hearing threshold } \\
\text { at better ear: } \\
50 \text { dB HL } \\
\text { Facilitator: SLP- } \\
\text { Audiologists with } \\
\text { little HA experience }\end{array}$ & $\begin{array}{l}\text { Polycom PVX } \\
\text { v8.0 software } \\
\text { LAN } 10 \text { Mbps. } \\
\text { Connection } \\
\text { speed } 384 \\
\text { kbps }\end{array}$ & $\begin{array}{l}\text { Duration: Teleconsultation } 1.1 \text { minute } \\
\text { longer than F-F }(+2 \%) \text {. } \\
\text { Counseling shorter in teleconsultation } \\
\text { ( } p<0.05) \\
\text { Larger difference between REIG and } \\
\text { NAl-NL1 targets at } 60 \text { and } 80 \mathrm{~dB} \text { SPL } \\
\text { for teleconsultation: } 0.78-2.14 \mathrm{~dB} \\
\text { ( } p<0.05) \\
\text { Hearing in Noise Test (HINT) } \\
\% \text { sentence recognition in silence: } \\
\text { F-F=56.2\% and Teleconsultation } \\
=51.7 \% \text { ( } p>0.05) \\
\text { S/N ratio: F-F=4.94 dB and } \\
\text { Teleconsultation=4.17 ( } p>0.05 \text { ) } \\
\text { Duration of hearing aid use: F-F } 36 \\
\text { days and Teleconsultation } 34 \text { days } \\
\text { ( } p>0.05 \text { ) } \\
\text { International Outcome Inventory for } \\
\text { Hearing Aids (IOI-HA) ( } p>0.05 \text { ) } \\
\text { Scores over } 3.5 \text { points in all domains }\end{array}$ & $\begin{array}{l}\text { Sporadic } \\
\text { problems in } \\
\text { audio and } \\
\text { video quality. } \\
\text { Interruption of } \\
\text { the procedure } \\
\text { due to loss } \\
\text { of internet } \\
\text { connection }\end{array}$ \\
\hline
\end{tabular}




\begin{tabular}{|c|c|c|c|c|c|}
\hline $\begin{array}{c}\text { Reference/ } \\
\text { Design }\end{array}$ & Purpose & Participants & Interactive video & Main outcome measures & Comments \\
\hline $\begin{array}{l}\text { Poles- } \\
\text { Reginato } \\
\text { \& Ferrari, } \\
2013 \text { [61] } \\
\text { RCT }\end{array}$ & $\begin{array}{l}\text { Assessment of } \\
\text { professional- } \\
\text { patient } \\
\text { communication } \\
\text { as well as patient } \\
\text { satisfaction with } \\
\text { the care provided }\end{array}$ & $\begin{array}{l}n=40 \\
\text { Mild to severe } \\
\text { sensorineural } \\
\text { bilateral HL } \\
\text { Age: } \bar{\chi} 69.5 \text { yrs } \\
\bar{\chi} \text { hearing threshold } \\
\text { at better ear: } 46.3 \\
\text { dB HL } \\
\text { F-F Group ( } n=20) \\
\text { and Teleconsultation } \\
(n=20) \text { matched } \\
\text { regarding age and } \\
\text { degree of hearing } \\
\text { loss. } \\
\text { Facilitator: SLP- } \\
\text { Audiologists without } \\
\text { HA experience }\end{array}$ & $\begin{array}{l}\text { Skype and } \\
\text { TeamViewer } \\
\text { software } \\
\text { LAN } 10 \text { Mbps. } \\
\text { Connection } \\
\text { speed } 384 \\
\text { kbps }\end{array}$ & $\begin{array}{l}\text { Duration: Teleconsultation } 4 \text { minutes } \\
\text { longer than F-F (+15\%) }(p<0.05) \\
\text { Professional-patient communication } \\
\text { (Davis Observation Code - DOC): } \\
\text { No significant difference between } \\
\text { F-F and Teleconsultation for } \\
\text { categories: active patient, prevention, } \\
\text { informational counseling. } \\
\text { Personal adjustment counseling } \\
\text { was not observed in any form of } \\
\text { consultation } \\
\text { Teleconsultations yielded higher rates } \\
\text { for technical behavior and lower rate } \\
\text { for health behavior categories ( } p<0.05) \text {. } \\
\text { Patient Experience Questionnaire (PEQ) } \\
\text { No significant difference between F-F } \\
\text { and Teleconsultation for categories: } \\
\text { outcomes of the consultation, } \\
\text { communication experiences and } \\
\text { communication barrier. } \\
\text { Teleconsultations yielded higher } \\
\text { scores for category “emotions after } \\
\text { consultation" ( } p<0.05 \text { ) } \\
\text { Patients reported positive experience } \\
\text { with the facilitator. }\end{array}$ & $\begin{array}{l}\text { Only one } \\
\text { audiologist } \\
\text { carried out } \\
\text { F-F and } \\
\text { teleco- } \\
\text { nsultations }\end{array}$ \\
\hline $\begin{array}{l}\text { Paiva, } \\
2015 \text { [62] } \\
\text { Quasi- } \\
\text { expe- } \\
\text { rimental } \\
\text { Pre and } \\
\text { post test }\end{array}$ & $\begin{array}{l}\text { Efficacy of } \\
\text { e-learning and } \\
\text { synchronous } \\
\text { teleconsultation } \\
\text { as clinical } \\
\text { preceptorship for } \\
\text { hearing aid real } \\
\text { ear measures } \\
\text { (REM) }\end{array}$ & $\begin{array}{l}n=50 \\
\text { SLP-Audiologists } \\
\text { dispensing hearing } \\
\text { aids in public } \\
\text { hearing healthcare } \\
\text { facilities in different } \\
\text { Brazilian regions } \\
\text { Control group } \\
(n=25): \\
\text { REM e-learning } \\
\text { Age: } \bar{\chi} 34 \text { yrs } \\
\text { HA experience: } \\
\bar{\chi} 7.5 \text { yrs } \\
\text { Previous REM } \\
\text { training: } 48 \% \\
\text { Experimental Group } \\
\text { ( } n=25) \text { : } \\
\text { REM e-learning and } \\
05 \text { synchronous } \\
\text { teleconsultations } \\
\text { each } \\
\text { Age: } \bar{\chi} 35 \text { yrs } \\
\text { HA experience: } \\
\bar{\chi} 6.3 \text { yrs } \\
\text { Previous REM } \\
\text { training: } 52 \%\end{array}$ & $\begin{array}{l}\text { TeamViewer } \\
\text { software } \\
\text { LAN } 10 \text { Mbps. } \\
\text { Connection } \\
\text { speed of } 384 \\
\text { kbps }\end{array}$ & $\begin{array}{l}\text { No statistical difference between } \\
\text { groups relating to access to e-learning } \\
\text { materials, assessment of instructor } \\
\text { performance and graphic interface. } \\
\text { Reaction towards e-learning: 24-item } \\
\text { instrument. Responses in a 5-point } \\
\text { Likert-type scale } \\
\text { No difference between groups } \\
\text { concerning content, utility, } \\
\text { development, results and support for } \\
\text { the training. } \\
\text { For both groups there were differences } \\
\text { between pre and post test scores } \\
\text { ( } p<0.05) \text { concerning REM interpretation } \\
\text { and clinical reasoning. } \\
\text { Teleconsultations: } \\
\text { From the second teleconsultation on: } \\
\text { decrease in duration }(p<0.05) \text { and } \\
\text { number of request for assistance while } \\
\text { carrying out REM }(p<0.05)\end{array}$ & $\begin{array}{l}\text { Sporadic } \\
\text { cuts in audio } \\
\text { and video } \\
\text { transmission }\end{array}$ \\
\hline
\end{tabular}




\begin{tabular}{|c|c|c|c|c|c|}
\hline $\begin{array}{l}\text { Reference/ } \\
\text { Design }\end{array}$ & Purpose & Participants & Interactive video & Main outcome measures & Comments \\
\hline $\begin{array}{l}\text { Campos, } \\
2016 \text { [63] } \\
\text { Mixed } \\
\text { methods }\end{array}$ & $\begin{array}{l}\text { Assessment of } \\
\text { professional- } \\
\text { patient } \\
\text { communication } \\
\text { in HA fitting } \\
\text { consultations } \\
\text { performed F-F } \\
\text { and at distance }\end{array}$ & $\begin{array}{l}n=60 \\
\text { Mild to severe } \\
\text { sensorineural } \\
\text { bilateral HL } \\
\text { F-F Group ( } n=30 \text { ) } \\
18 \text { men, } 12 \text { women } \\
\text { Age: } \bar{\chi} 69 \text { yrs } \\
\bar{\chi} \text { hearing threshold } \\
\text { at better ear: } 50,8 \\
\text { dB HL } \\
\text { Teleconsultation } \\
(n=30) \\
14 \text { men, } 16 \text { women } \\
\text { Age: } \bar{\chi} 69 \text { yrs } \\
\bar{\chi} \text { hearing threshold } \\
\text { at better ear: } 46,2 \\
\text { dB HL } \\
\text { SLP-Audiologists } \\
5 \text { audiologists with } \\
5 \text { yrs experience in } \\
\text { hearing aid fittings } \\
\text { Age: } \bar{\chi} 33.4 \text { yrs } \\
\text { Facilitators } \\
4 \text { SLP-Audiology } \\
\text { graduate students } \\
\text { with no experience } \\
\text { in HA fitting }\end{array}$ & $\begin{array}{l}\text { TeamViewer } \\
\text { v10 software } \\
\text { LAN } 10 \text { Mbps. } \\
\text { Connection } \\
\text { speed of } 384 \\
\text { kbps }\end{array}$ & $\begin{array}{l}\text { Duration: on average teleconsulations } \\
\text { lasted } 10 \text { minutes longer. } \\
\text { Video recording of the consultations } \\
\text { analyzed by two independent } \\
\text { examiners by means of Global } \\
\text { Consultation Rating Scale (GCRS) } \\
\text { - higher scores mean better } \\
\text { communication: } \\
\text { F-F: } \bar{\chi} 15.3 \text {; Teleconsultation: } \\
\bar{\chi} 12.6(p<0.05) \\
\text { High scores or close to the maximum } \\
\text { were not found in any of the cases } \\
\text { Thematic analysis of } 10 \text { consultations } \\
\text { F-F ( } n=5) \text { and Teleconsultations ( } n=5) \text { : } \\
\text { For both consultations the professional } \\
\text { or, when present, the facilitator's talk } \\
\text { was predominant. The communication } \\
\text { content was biomedical in essence, } \\
\text { mostly related to hearing aid use and } \\
\text { handling }\end{array}$ & $\begin{array}{l}\text { Technical } \\
\text { problems } \\
\text { occurred in } \\
27 \% \text { of tele- } \\
\text { consultation, } \\
\text { being } \\
\text { necessary to } \\
\text { interrupt and } \\
\text { restart them }\end{array}$ \\
\hline
\end{tabular}

RCT - randomized controlled trial; LAN - local area network; HL - hearing loss; F-F - face-to-face; yrs - years; Mbps megabits per second; kbps - kilobits per second; REUR - real ear unaided response; REAR - real ear aided response; REIG - real ear insertion gain; REM - real ear measures.

remote desktop control for hearing aid fittings. On average, telehealth increased the duration of the procedures/ appointments $[58,60,61]$, mainly due to additional steps inherent in this method (e.g. connectivity delays, instructing the facilitator). This affects the clinic schedule in the short run. However, since neither the patient nor the professional have to relocate, an overall improvement in efficiency is possible.

With regards to real ear measures, differences between face-to-face and remote procedures were statistically significant, although not clinically $[59,60]$. It was noted that the onsite professionals were able to independently perform the procedure after taking part in a few remote sessions, thus showing that teleconsultations can be used for clinical preceptorship [63]. Additionally, when compared to conventional methods, teleconsultation for hearing aid fitting did not yield significant differences for speech-innoise results or for the device's usage, benefit, and satisfaction [60].

The use of ICT influenced professional-patient communication. Professionals spent more time delivering technical information and carrying out procedures and fewer spontaneous comments from patients were noted. It is also worth mentioning that patient-centered communication was not observed either in face-to-face sessions or in teleconsultations $[61,63]$. Therefore, there is a need for professionals to develop more effective communication skills and, when using teleconsultations, consider media training.

\section{Concluding comments}

The need to expand the use of information and communication technologies for healthcare delivery, including hearing healthcare, has come about from pressing worldwide problems, particularly affecting developing countries: population growth and aging, increased demand for healthcare, income inequality, geographical barriers, lack of properly trained professionals, and the need to offer the best possible care within increasingly tight budget constraints.

The research conducted at Bauru Dental School indicates that these issues - as well as challenges arising from shortages of well-trained audiologists [23], lack of the use of real ear measures [19], and patient absenteeism [29] - can be mitigated by incorporating remote hearing aid fitting routinely into public hearing healthcare clinics. However, in order to do this, a more constructive interaction among stakeholders, including policy makers, key opinion leaders, and legal/regulatory bodies is required.

The feasibility of implementing audiology telehealth, including remote hearing aid fitting, at subsidized services in other countries has also been investigated. Australian Hearing Services' pilot program indicated hearing aid fitting and fine-tuning could be successfully performed via telehealth [64]. In the United States Department of Veterans Affairs, a comparison of two cohorts of veterans, fitted with hearing aids via face-to-face and telehealth models, showed similar hearing aid outcomes [65]. 
In addition, technical development is occurring at an unprecedented speed. Despite the existing digital divide, more present in developing countries, the affordability of internet-ready devices and wearables, social media, alternative broadband internet connections, and big data, to name a few, are reshaping our society and, consequently, healthcare systems. Overall, telehealth has the potential to help healthcare providers meet the demands of a technologically increasing society.

\section{Acknowledgements}

Support for this work came from the Conselho Nacional de Desenvolvimento Científico e Tecnológico - CNPq. Process \#486843/2013-0.

This work was co-financed by the National Centre for Research and Development within the STRATEGMED program (project "Integrated system of tools designed for diagnostics and telerehabilitation of sense organ disorders (hearing, vision, speech, balance, smell, taste), acronym INNOSENSE".

\section{References:}

1. World Bank. Brazil. 2016. Downloaded 2017 Mar 28; available at $h t t p: / / d a t a . w o r l d b a n k . o r g / c o u n t r y / b r a z i l$ [in Portuguese].

2. PNUD (Programa das Nações Unidas para o Desenvolvimento). "Atlas Brasil 2013. Atlas do desenvolvimento humano do Brasil” 2013. Downloaded 2017 Mar 28; available at $h t t p: / /$ www.atlasbrasil.org.br/2013/ [in Portuguese].

3. IBGE (Instituto Brasileiro de Geografia e Estatística). "Pesquisa nacional por amostra de domicílio", 2013. Downloaded 2017 Mar 28; available at $h t t p: / / w w w . i b g e . g o v . b r / h o m e / e s t a t i s-$ tica/populacao/condicaodevida/indicadoresminimos/sinteseindicsociais2010/default.shtm [in Portuguese].

4. IBGE (Instituto Brasileiro de Geografia e Estatística). "Esperança de vida ao nascer", 2016.Downloaded 2017 Mar 28; available at $h t t p: / / b r a s i l e m s i n t e s e . i b g e . g o v . b r / p o p u l a c a o / e s p e r a n c a s-$ de-vida-ao-nascer.html [in Portuguese].

5. IBGE (Instituto Brasileiro de Geografia e Estatística). "Pesquisa Nacional de Saúde”, 2013. Downloaded 2017 Mar 28; available at $h t t p: / / w w w . i b g e . g o v . b r / h o m e / e s t a t i s t i c a / p o p u l a c a o / p n s / 2013$ vol2/default.shtm [in Portuguese].

6. Montekio VB, Medina G, Aquino R. The health system of Brazil. Salud Pública Méx, 2011; 53: 120-31.

7. Paim J, Travassos C, Almeida C, Bahia L, Macinko J. O sistema de saúde brasileiro: história, avanços e desafios. Series papers, Lancet, 2011, 11-31 [in Portuguese]; 377: 1778-97 [in English].

8. Brasil. Ministério da Saúde. Secretaria Nacional de Assistência à Saúde. "ABC do SUS: doutrinas e princípios", 1990. Downloaded 2017 Mar 28; available at http://www.pbh.gov.br/smsa/bibliografialabc_do_sus_doutrinas_e_principios.pdf[in Portuguese].

9. Brasil. Ministério da Saúde. Portal da Saúde. "Entenda o SUS", 2014. Downloaded 2017 Mar 28; available at $h t t p: / / p o r t a l s a u d e$. saude.gov.br/index.php/cidadao/entenda-o-sus [in Portuguese].

10. Béria JU, Raymann BCW, Gigante LP, Figueiredo ACL, Jotz G, Roithman R et al. Hearing impairment and socioeconomic factors: A population-based survey of an urban locality in southern Brazil. Rev Panam Salud Publica, 2007; 6: 381-87.

11. Brasil. Ministério da Saúde. Secretaria de Assistência à Saúde. Portaria SAS/MS no. 126, de 17 de setembro de 1993. "Cria os grupos e procedimentos na tabela de procedimentos do Sistema de Informações Hospitalares do Sistema Único de Saúde", 1993. http://sna.saude.gov.br/legisla/legisla/alta_impl_coc/ [in Portuguese].

12. Brasil. Ministério da Saúde. Secretaria de Assistência à Saúde. Portaria SAS/MS no. 211, de 08 de novembro de 1996. "Estabelece que os procedimentos de Cirurgia do Ouvido IV e Implante Coclear só poderão ser utilizados por Centro/Núcleo previamente credenciado, segundo normas fixadas". http://sna. saude.gov.br/legisla/legisla/alta_impl_coc/ [in Portuguese].
13. Brasil. Ministério da Saúde. Portaria no. 3.764 de 20 de outubro de 1998. "Institui o cadastro de unidades prestadoras de serviços de diagnóstico e avaliação do deficiente auditivo e a autorização de procedimentos de alto custo em deficiência auditiva" [in Portuguese].

14. Bevilacqua MC, Melo TM, Morettin M, Lopes AC. A avaliação de serviços em audiologia: concepções e perspectivas. Rev Soc Bras Fonoaudiol, 2009; 3: 421-26 [in Portuguese].

15. Brasil. Ministério da Saúde. Gabinete do Ministro. Portaria GM no. 2073 de 28 de setembro de 2004. "Institui a Política Nacional de Atenção à Saúde Auditiva”. http://dtr2001.saude.gov. br/sas/portarias/Port2004/GM/GM-2073.htm [in Portuguese].

16. Brasil. Ministério da Saúde. Secretaria de Assistência a Saúde. Portaria SAS/MS no. 587 de 07 de outubro de 2004. "Determina que as Secretarias de Estado da Saúde dos estados adotem as providências necessárias à organização e implantação das Redes Estaduais de Atenção à Saúde Auditiva e de outras providências". http://dtr2001.saude.gov.br/sas/portarias/ Port2004/PT-587.htm [in Portuguese].

17. Brasil. Ministério da Saúde. Secretaria de Assistência a Saúde. Portaria SAS/MS no. 589 de 08 de outubro de 2004. “Trata dos mecanismos para operacionalização dos procedimentos de atenção à saúde auditiva no Sistema Único de Saúde - SIA/SUS". http://dtr2001.saude.gov.br/sas/portarias/Port2004/PT-589.htm [in Portuguese].

18. Brasil. Presidência da República. Lei $\mathrm{n}^{\circ} 12.303$, de 2 de agosto de 2010. "Dispõe sobre a obrigatoriedade de realização do exame denominado Emissões Otoacústicas Evocadas". Brasília: Casa Civil, Subchefia para Assuntos Jurídicos, 2010 [in Portuguese].

19. Bevilacqua MC, Morettin M, Melo TM, Amantini RCB, Martinez MANS. Contribuições para análise da política de saúde auditiva no Brasil. Rev Soc Bras Fonoaudiol, 2011;3: 252-59 [in Portuguese].

20. Andrade CL, Fernandes L, Ramos HE, Mendes CMC, Alves CAD. Programa Nacional de Atenção à Saúde Auditiva: avanços e entraves da saúde auditiva no Brasil. Rev Ciênc Méd Biol, 2013;4: 404-10 [in Portuguese].

21. da Silva LSG, Gonçalves CGO, Soares VMN. National Policy on Health Care Hearing: an evaluative study from covering services and diagnostic procedures. CoDAS, 2014; 26(3): 241-47.

22. Teixeira CF. Estudo avaliativo da política de atenção à saúde auditiva: estudo de caso em Pernambuco - Recife [Thesis]. Recife (PE): Fundação Oswaldo Cruz, Centro de Pesquisas Ageu Magalhães; 2007 [in Portuguese]. 
23. Conselho Federal de Fonoaudiologia. Pesquisa mapeia a situação dos serviços de saúde auditiva no Brasil. Comunicar Revista do sistema de conselhos Federal e Regionais de Fonoaudiologia, 2012; 54: 6-7 [in Portuguese].

24. Brasil. Presidência da República. Decreto no. 7612, de 11 de novembro de 2011. "Institui o Plano Nacional dos Direitos da Pessoa com Deficiência - Plano Viver sem Limite.” 2011. http:// www.planalto.gov.br/CCIVIL_03/_Ato2011-2014/2011/Decreto/ D7612.htm [in Portuguese].

25. Brasil. Ministério da Saúde. Portaria no. 793, de 24 de abril de 2012. "Institui a rede de cuidados à pessoa com deficiência no âmbito do Sistema Único de Saúde”, 2012. http://bvsms.saude. gov.br/bvs/saudelegis/gm/2012/prt0793_24_04_2012.html [in Portuguese].

26. Brasil. Ministério da Saúde. Portaria no. 1.274, de 25 de junho de 2013. "Inclui o procedimento de Sistema de Frequência Modulada Pessoal (FM) na tabela de procedimentos, medicamentos, órteses, próteses e materiais especiais (OPM) do Sistema Único de Saúde”. http://bvsms.saude.gov.br/bvs/saudelegis/gm/2013/prt1274_25_06_2013.html [in Portuguese].

27. Brasil. Ministério da Saúde. Saúde sem limite. "Instrutivos de reabilitação auditiva, física, intelectual e visual”, 2013. http:// www.saude.ms.gov.br/controle/ShowFile.php?id=145293 [in Portuguese].

28. Rezende EJC, Melo MCB, Tavares EC, Santos AF, Souza C. Ética e telessaúde: reflexões para uma prática segura. Rev Panam Salud Publica, 2010;1: 58-65 [in Portuguese].

29. Gomes MM. Programa de saúde auditiva: perfil dos usuários e avaliação dos resultados obtidos na intervenção fonoaudiológica. Universidade Estadual de Campinas Faculdade de Ciências Médicas [Masters thesis], 2014 [in Portuguese].

30. Goulios H, Patuzzi RB. Audiology education and practice from an international perspective. Int J Audiol, 2008; 10: 647-64.

31. Windmill IM, Freeman BA. Demand for audiology services: 30 year projections and impact on academic programs. J Am Acad Audiol, 2013; 24: 407-16.

32. Behlau M, Gasparini G. Education of speech-language pathologists and audiologists in Brazil. Folia Phoniatr Logop, 2006; 58: 14-22.

33. Bevilacqua MC, Novaes BC, Morata TC. Audiology in Brazil. Int J Audiol, 2008; 47: 45-50.

34. Vianna NG, Cavalcanti MLT, Acioli MD. Princípios de universalidade, integralidade e equidade em um serviço de atenção à saúde auditiva. Ciênc Saúde Coletiva, 2014; 7: 2179-88 [in Portuguese]

35. Watts J. Brazil's health system woes worsen in economic crisis. Lancet, 2016; 10028: 1603-4.

36. Craig J, Patterson V. Introduction to the practice of telemedicine. J Telemed Telecare, 2005; 11(1): 3-9.

37. Abbott PA, Liu Y. A scoping review of telehealth. Yearb Med Inform. 2013; 8: 51-58.

38. Bickenbach J, Degener T, Melvin J, Quinn G, Posarac A, Schulze $\mathrm{M}$ et al. Entendendo a deficiência. In: Hartley S, Ilagan V, Madden R, Officer A, Posarac A, Seelman K et al., editors. Relatório Mundial Sobre a Deficiência. Trad Lexicus Seviços Linguísticos, Sao Paulo; 2011 [in Portuguese].

39. World Health Organization. Telemedicine: opportunities and developments in member states: report on the second global survey on eHealth 2009. Geneva: WHO; 2010. http://www. who.int/goe/publications/goe_telemedicine_2010.pdf.

40. Bashshur R, Shannon G, Krupinski E, Grigsby J. The taxonomy of telemedicine. Telemed J E Health, 2011; 6: 484-94.
41. World Health Organization. mHealth: New horizons for health through mobile technologies: second global survey on eHealth. Geneva: WHO; 2011. www.who.int/goe/publications/ goe_mhealth_web.pdf.

42. Krumm M, Ferrari DV. Contemporary telehealth and telemedicine applications in audiology. Audiology Today, 2008; 5: $36-41$.

43. Freeman BA. Technology, legislators, associations, and companies are encouraging tele-audiology. Hear J, 2010; 6: 50-51.

44. Conselho Federal de Fonoaudiologia. Resolução CFFa no. 427, de $1^{\circ}$ de março de 2013 "Dispõe sobre a regulamentação da Telessaúde em Fonoaudiologia e dá outras providências." http://www.fonoaudiologia.org.br/legislacaoPDF/Res\%204272013.pdf [in Portuguese].

45. Khouri, SG. Telemedicina: análise da sua evolução no Brasil. [Dissertation]. Sao Paulo (SP): Faculdade de Medicina. Universidade de Sao Paulo, 2003. http://www.teses.usp.br/teses/disponiveis/5/5160/tde-24102007-143128/pt-br.php [in Portuguese].

46. Chao LW. Telemedicina e telessaúde. Informática Pública, 2008; 2: 7--15 [in Portuguese].

47. Brasil. Ministério da Saúde. Portaria no. 561 de 16 de março de 2006. "Institui, no âmbito do Ministério da Saúde, a Comissão Permanente de Telessaúde". http://aps.bvs.br/legislacao/?l=pt_ $B R$ [in Portuguese].

48. Campos FE, Haddad AE, Wen CL, Alkmin MBM, Cury PM. The National Telehealth Program in Brazil: An instrument of support for primary health care. Latin-Am J Telehealth, 2009; 1: 39-66.

49. Brasil. Ministério da Saúde. Portaria no 35, de 04 de janeiro de 2007. "Institui, no âmbito do Ministério da Saúde, o Programa Nacional de Telessaúde”. http://bvsms.saude.gov.br/bvs/saudelegis../gm/2007/prt0035_04_01_2007.html [in Portuguese].

50. Haddad AE. Experiência brasileira do Programa Nacional Telessaúde Brasil. In: Mathas I, Monteiro A. "Goldbook Inovação Tecnológica em Educação e Saúde”. 50 Congresso Científico da HUPE. 2012. http://www.telessaude.uerj.br/resource/goldbook/pdf/2.pdf [in Portuguese].

51. Brasil. Ministério da Saúde. Portaria no. 402 de 24 de fevereiro de 2010. "Institui, em âmbito nacional, o Programa Telessaúde Brasil para apoio à Estratégia de Saúde da Família no Sistema Único de Saúde" [in Portuguese].

52. Chao LW. Telemedicina e Telessaúde: Inovação e Sustentabilidade As experiências da Disciplina de Telemedicina (DTM) da Faculdade de Medicina da Universidade de Sao Paulo. In: Mathas I, Monteiro A. "Goldbook Inovação Tecnológica em Educação e Saúde”. 50 Congresso Científico da HUPE. 2012. http://www.telessaude.uerj.br/resource/goldbook/pdf/5.pdf [in Portuguese].

53. Brasil. Ministério da Saúde. Portaria n 2.546 , de 27 de outubro de 2011. "Redefine e amplia o Programa Telessaúde Brasil, que passa a ser denominado Programa Nacional Telessaúde Brasil Redes". http://www.telessaudebrasil.org.br [in Portuguese].

54. Brasil. Ministério da Saúde. Portaria nº 2.554, de 28 de outubro de 2011. "Institui, no Programa de Requalificação de Unidades Básicas de Saúde, o Componente de Informatização e Telessaúde Brasil Redes na Atenção Básica, integrado ao Programa Nacional Telessaúde Brasil Redes." http://bvsms.saude. gov.br/bvs/saudelegis/gm./2011/prt2554_28_10_2011.html [in Portuguese].

55. Brasil. Ministério da Saúde. "Custeio dos Núcleos de Telessaúde". Manual Instrutivo. Brasilia, 2015. http://189.28.128.100/ dab/docs/portaldab/documentos/manual_tecnico_telessaude_ preliminar.pdf [in Portuguese]. 
56. Brasil. Ministério da Saúde. Portaria no. 2.013, de 14 de setembro de 2012. "Institui Grupo de Trabalho, no âmbito do Ministério da Saúde, com a finalidade de avaliar, discutir e propor critérios e ações para expansão do Programa Nacional Telessaúde Brasil Redes". http://bvsms.saude.gov.br/bvs/saudelegis/gm/2012/prt2013_14_09_2012.html [in Portuguese].

57. Santos AF, Sobrinho DF, Lima AMD, Jorge AO, Machado TAM. ICT in primary care in Brazil: current situation. Latin Am J Telehealth, 2016; 2: 192-99.

58. Ferrari DV. Remote programming and verification as a mean to improve quality of hearing aid fitting. In: Rasmussen AN, Andersen T, Larsen CB. Hearing aid fitting. $1^{\text {st }}$ ed, Centertryk: Danavox Jubilee Foundation. 2006; pp. 531-44.

59. Ferrari DV, Bernardez-Braga GRA. Remote probe microphone measurement to verify hearing aid performance. J Telemed Telecare, 2009; 15(3): 122-24.

60. Campos PD, Ferrari DV. Teleaudiology: Evaluation of teleconsultation efficacy for hearing aid fitting. J Soc. Bras Fonoaudiol, 2012; 24(4): 301-8.
61. Reginato, TTP, Ferrari, DV. Teleaudiology: Professional-patient communication in hearing aid programming and fitting via teleconsultation. Audiol Commun Res, 2014; 3: 299-309.

62. Paiva PMP. Telessaúde e audiologia: teleconsulta para o preceptorado clínico na verificação dos aparelhos de amplificação sonora individuais. [Dissertation]. Bauru (SP): Universidade de Sao Paulo, Faculdade de Odontologia de Bauru, 2015 [in Portuguese].

63. Campos PD. Teleaudiologia: análise da comunicação profissional/paciente no processo de seleção e adaptação de aparelhos de amplificação sonora individuais via teleconsulta. [Thesis]. Bauru (SP): Universidade de Sao Paulo, Faculdade de Odontologia de Bauru, 2016 [in Portuguese].

64. Pearce W, Ching T, Dillon H. A pilot investigation into the provision of hearing services using tele-audiology to remote areas. Aust NZ J Audiol, 2009; 2: 96-100.

65. Gladden C, Beck L, Chandler D. Tele-audiology: expanding access to hearing care and enhancing patient connectivity J Am Acad Audiol, 2015; 9: 792-99. 